\title{
Úvodník trochu netradičně
}

\author{
KLÁRA Uličná
}

\begin{abstract}
Vážené čtenářky, vážení čtenáři,
je tomu rok, co se s Vámi na tomto místě loučil Martin Chvál v roli vedoucího redaktora. K vedení časopisu Pedagogika jsem v té době přistoupila a stále přistupuji s pokorou, ale i s obavou, abych dokázala dostát očekáváním odborné veřejnosti, očekáváním čtenářů, a současně časopis provést obdobím, $\mathrm{v}$ němž dochází $\mathrm{k}$ proměnám v hodnocení vědy a vědeckého výkonu.

Časopis Pedagogika má dlouholetou tradici. V tomto roce vydáváme 70. ročník časopisu. Cítím potřebu vyjádřit dík všem vedoucím redaktorům, kteří časopis s podporou výkonných redakcí prováděli různými obdobími. Díky nim je Pedagogika českým periodikem s nejdelší tradicí a současně periodikem, které je stále atraktivní pro čtenáře i autory. Můj předchůdce, Martin Chvál, dokázal za podpory děkanky Pedagogické fakulty Univerzity Karlovy, prof. Radky Wildové, vzdát hold všem svým předchůdcům vytvořením archivu časopisu, který otevírá možnost nahlédnout (nejen) do proměn pojetí pedagogiky. V průběhu roku 2019 jsme činnost časopisu na původních webových stránkách ukončili s tím, že zůstaly funkční právě jako elektronický archiv všech čísel od založení časopisu do roku 2018 (https://pages.pedf.cuni.cz/pedagogika/?lang=cs). Běh časopisu dále pokračuje na nově založených webových stránkách pod redakčním systémem Open Journal System (https://ojs.cuni.cz/pedagogika). Současně bych na tomto místě ráda Martinovi poděkovala osobně, jelikož to byl právě on, kdo mě do výkonné redakce časopisu Pedagogika přizval a po letech mi její vedení předal, přičemž v průběhu prvního roku mého působení $\mathrm{v}$ roli vedoucí redaktorky mi byl významnou oporou nejen on, ale i celá výkonná redakce časopisu.

Jako poděkování svým předchůdcům vyjádřím př́íslib, že budu i nadále zastávat zavedený postoj časopisu Pedagogika $\mathrm{k}$ autorům i čtenářům. Jedná se především o osobní přístup $\mathrm{k}$ autorům, ale
\end{abstract}


současně i důraz na odbornou kvalitu textů. Výkonná redakce klade na publikované texty vysoké nároky. Věrím, že tyto postoje dělají časopis Pedagogika tím, čím je. Současně se však v poslední době setkáváme s texty, které svým charakterem nespadají do standardně vymezených „kolonek“; jedná se především o texty na pomezí studií a diskusních příspěvků či analytických zpráv. Předmětem našich úvah je tudíž dodržování vymezených standardů odborných studií a současně atraktivita časopisu pro čtenáře, jelikož sdílení $\mathrm{v}$ odborné komunitě považujeme za zásadní poslání obdobně orientovaných časopisů. Zařadit do časopisu Pedagogika formát moderovaných diskusí či předběžných sdělení vnímáme ve výkonné redakci jako príležitost $\mathrm{k}$ tomuto sdílení a prýnos pro pedagogickou komunitu v současném měnícím se (nejen akademickém) světě. Těžkostí, $s$ níž se v souvislosti s texty potýkáme, je průběžné získávání renomovaných zahraničních autorů (nejen) pro plánovaná cizojazyčná monotematická čísla. Uvedené úvahy a současný stav jsou významně determinovány již nastíněným problémem souvisejícím $s$ hodnocením vědy nejen v České republice. Časopis Pedagogika na straně jedné bezesporu patř́ mezi kvalitní časopisy, na straně druhé není indexován v databázích jako Web of Science či SCOPUS, čímž se v současných publikačních strategiích autorů často stává periodikem tzv. druhé volby. Naším cílem je tudíž dostát nárokům na kvalitu, což věřím, že činíme, ale současně $\mathrm{v}$ návaznosti na úspěšná cizojazyčná monotematická čísla $s$ mezinárodním přesahem zažádat $o$ indexaci časopisu v databázi SCOPUS a výhledově i dalších databázích. $V$ současné době plníme formální kritéria pro podání žádosti, nicméně co do zahraničního dopadu časopisu se tzv. točíme v kruhu. Publikační strategie totiž vedou zejména zahraniční autory $\mathrm{k}$ publikování $\mathrm{v}$ časopisech $\mathrm{v}$ těchto databázích indexovaných, avšak bez těchto autorů není možné překročit hranice regionálního časopisu a do daných databází vstoupit, príp. se v nich následně udržet. Přesto tento krok vnímám jako výzvu, kterou se budeme snažit naplnit.

$\mathrm{V}$ řadě mých poděkování nemohu opomenout Pedagogickou fakultu Univerzity Karlovy a její podporu časopisu, který svým charakterem není spravován vybraným pracovišstěm. Je časopisem náležejícím odborné pedagogické komunitě, a proto je pro něj podpora Pedagogické fakulty Univerzity Karlovy stěžejní. Nastíněný charakter časopisu Pedagogika se zrcadlí i ve složení jeho výkonné redakce. Jedná se bez nadsázky o skupinu osobností ve svých oborech. Pro mě se nyní jedná o kolegyně a kolegy, kteří - ač pocházejí z různých českých univerzit - se časopisu průběžně věnují, nabízejí mu svou profesní moudrost a významně pomáhají $s$ výběrem a kultivací textů, ale mnohdy i s garantstvím monotematických čísel.

$\mathrm{V}$ neposlední řadě patří můj dík autorům. Jsme rádi, že po drobném propadu v počtu zasílaných textů došlo ke stavu, kdy máme ve výkonné redakci a $\mathrm{v}$ redakčním procesu dostatek kvalitních a zajímavých textů, a to nejen studií, ale i př́spěvků diskusních, kterých si obzvlášt ceníme - považujeme je za velký př́nos profesní komunitě a jsme rádi, že autoři volí právě Pedagogiku jako svou diskusní platformu. Mám osobní potěšení, že deklarovaná kvalita textů a zá- 
jem pedagogické komunity o diskusi se odráží již v prvním čísle roku 2020, které sestává ze čtyř studií (jedné teoretické studie a tří různorodých výzkumných studií), tř́i diskusních příspěvkủ a jedné analytické zprávy.

Teoretická studie Stanislava Štěpáníka predstavuje koncepci komunikační nauky o českém jazyku, jíž se autor dlouhodobě věnuje. Ve svém příspěvku se autor zabývá obecnými východisky se zvláštním důrazem na vztah oboru a školního předmětu, přičemž vybranou problematiku nahližź jak z perspektivy oborové didaktiky, resp. didaktiky českého jazyka, tak z perspektivy transdisciplinární didaktiky. $\mathrm{V}$ tomto kontextu však upozorňuje na specifické postavení českého jazyka, resp. učitelů této profesní subkultury oproti učitelům jiných školních předmětů, které vychází především z povahy objektu poznání předmětu český jazyk.

Výzkumná studie Idy Viktorové nabízí odpovědi na otázky spojené se subjektivním vnímáním komunikace $s$ rodiči učiteli základních škol. Autorka $\mathrm{k}$ dané problematice přistupuje jak z pohledu učitelů, kteří jsou $\mathrm{v}$ profesi spokojeni, tak z pohledu učitelů, kteří se v profesi cítí méně spokojeni, resp. učitelů s nastupujícím syndromem vyhoření.

Ústředním motivem výzkumné studie Moniky Kadrnožkové je vnitřní diferenciace žáků v rámci výběrových základních škol, přičemž autorka mimo jiné hledá souvislost mezi výsledky žáků a přidělováním učitelů do tříd vedením škol. Hlavním cílem realizovaného šetření bylo odhalit, $\mathrm{zda}-\mathrm{a}$ prrípadně podle jakých kritérií - vedení vybraných škol přiděluje učitele do výběrových a dalších tříd.

Poslední výzkumná studie, jejíž autorkou je Eva Ellederová, je ukotvena doménově specificky. Autorka představuje konstrukční výzkum pilotní verze učebnice anglického jazyka pro specifické účely spolu $s$ prvními výsledky realizovaného šetření a obecněji pojatými doporučeními pro autory učebnic, která vyplynula z vlastního šetření autorky.

Diskusní vlákno otevírá Jan Průcha textem Pedagogický výzkum a využití v praxi - téma pro diskusi. Autor ze své dlouholeté zkušenosti $\mathrm{v}$ této oblasti reaguje na současný stav pedagogického výzkumu a vyzývá $\mathrm{k}$ diskusi o něm. Zejména poukazuje na významný rozkvět pedagogického výzkumu co do objemu i metodologie, což kontrastuje se skutečností, že k využívání výsledků v praxi dochází pouze v omezené míre. Nicméně připomíná inspirativní počiny propojující různým způsobem výsledky pedagogického výzkumu s praxí, at již ve formě vzájemného souznění různých aktérů, či doporučení. V závěru nabízí J. Průcha čtyři oblasti, které považuje za diskuse hodné.

K reakci na diskusní text J. Průchy jsme oslovili vybrané kolegyně a kolegy a podařilo se nám získat reakce dvou z nich. První diskutující, Michaela Spurná, která je oproti J. Průchovi výzkumníkem začínajícím, ve svém prríspěvku Mezi výzkumem a praxí: Pasteurův kvadrant jako př́ležitost ke změně přistoupila $\mathrm{k}$ diskusi originálně. Otevřela ji otázkou, kterou sama sobě kladla $\mathrm{v}$ počátcích svého bádání: $\mathrm{K}$ čemu vlastně pedagogický výzkum je a komu má sloužit? Odpověd' na tuto otázku hledala již ve své magisterské i disertační práci, $\mathrm{v}$ nichž se zabývala využíváním pedagogického výzkumu učiteli a metodologií přenosu poznatků pedagogického výzkumu do praxe. Ve svém diskusním prríspěvku k odpovědi na svou otázku zvolila, 
jak již samotný název jejího příspěvku napovídá, Pasteurův kvadrant a poznatky jeho pomocí generované, jež mimo jiné označuje za inovativní a př́mo prospěšné pro školní praxi i vědu. Poukazuje na př́nos takového výzkumu, který „zkracuje cestu mezi tvůrci a odběrateli výzkumných poznatků a umožňuje užitečně využívat poznatky obou světư - světa výzkumu a světa praxe.

Druhým diskutantem je Stanislav Štech, který v textu Trápení $s$ užitečností pedagogického výzkumu: Jen ztraceni v překladu? reaguje př́mo na tři J. Průchou „nezodpovězené otázky“. Autor se domnívá, že odpovědi lze nalézt pouze prostřednictvím jejich propojení, prričemž do popředí svých úvah staví aktéry, s nimiž propojuje povahu realizovaného výzkumu a $\mathrm{v}$ neposlední řadě účel jeho př́ípadného využívání v praxi. Svou argumentaci strukturuje podle dvou stěžejních aktérů, $\mathrm{k}$ nimž vztahuje úvahy o využivání výzkumných výsledků. $\mathrm{V}$ první řadě jsou to politici v decizní sféře a s nimi rovněž experti, jejichž úlohou je výsledky výzkumu (nejen) politikům zprostředkovávat. V tomto ohledu píše S. Štech o imperativu rozhodovat $s$ oporou o vědecké důkazy (evidence-based policy). V druhé řadě, ač obvyklejší, pak stojí v úvahách autora učitel, resp. prístup označovaný jako praxe založená na výzkumných důkazech (evidence-based practice). V tomto případě hovoří $S$. Štech o príijetí výzkumných poznatků učiteli: surovina praktické zkušenosti vs. vzácná ruda poznání.
Poděkování patří J. Průchovi za otevření této diskuse, nemenší M. Spurné a S. Štechovi za jejich reakce. Je zřejmé, že každý z autorů nabízí odlišný pohled na diskutovanou problematiku. Za diskusi na toto téma jsme rádi a doufáme, že bude na stránkách časopisu dále pokračovat.

Diskusi svým způsobem doplňuje analytická zpráva Dominika Dvořáka a Jana Vyhnálka referující o každoroční konferenci Evropské asociace pedagogického výzkumu (EERA) konané $\mathrm{v}$ Hamburku 2.-6. záŕí 2019. Mottem konference bylo vzdělávání v době rizik - role a odpovědnost pedagogického výzkumu vzhledem $\mathrm{k}$ budoucnosti. Autoři připravili pro čtenáře Pedagogiky opravdu podrobnou zprávu z této konference. Úvodní část se podrobně věnuje plenární přednášce Dirka Van Damma z organizace OECD $\mathrm{k}$ přenosu výzkumných poznatků do vzdělávací politiky a praxe. Další části této podrobné zprávy, do nichž autoři vložili i svůj pohled, jsou věnovány oblastem spojeným $s$ jejich vlastním výzkumem. Konkrétně se zamérili na témata kurikulum a kompetence, odborné školství a jeho proměny, kvalita žáků a studentů.

Při zpětném čtení tohoto úvodníků si uvědomuji, že by bylo vhodné a tzv. IN stanovit si vznešené vize. Nemám je, nicméně vyslovila jsem svá poděkování, své obavy, ale i závazky, kterým se pokusím dostát. A v této obecně nestandardní době přeji vám všem zdraví a časopisu Pedagogika vaši přízeň. 